\title{
Metallurgical Behaviour and Carbon Diffusion in Buttering Deposits Prepared With and Without Buffer Layers
}

\author{
Dinesh W. Rathod ${ }^{1,2} \cdot$ Sunil Pandey $^{1} \cdot$ Sivanandam Aravindan $^{1} \cdot$ Pavan Kumar Singh $^{3}$
}

Received: 30 April 2016/Revised: 28 August 2016/Published online: 21 September 2016

(C) The Chinese Society for Metals and Springer-Verlag Berlin Heidelberg 2016

\begin{abstract}
Use of a buttering deposit on ferritic steel in dissimilar metal weld (DMW) joint is a common practice in nuclear plants to connect pressure vessel components (ferritic steel) to pipelines (austenitic stainless steel). Carbon migration and metallurgical changes near fusion interface (ferritic steel-austenitic stainless steel) lead to a steeper gradient in material properties, and minimizing this gradient is the major challenge in the manufacturing of DMW joints. Inconel 82 is often deposited on ferritic steel material as buttering to reducing the gradient of physical and attaining material compatibility. Inconel 82/182 fillers are used to minimize the carbon migration, but the results are not truly adequate. In this paper, $\mathrm{Ni}-\mathrm{Fe}$ alloy (chromium-free) has been used as the intermediate buffer layer in the weld buttering deposit to address the issue of carbon migration and subsequent metallurgical deterioration. The weld pads with and without buffer layers of Ni-Fe alloy have been investigated and compared in detail for metallurgical properties and carbon diffusivities. Ni-Fe buffer layer can significantly control the carbon migration which resists the metallurgical deterioration. It showed the better results in postweld heat treatment and thermally aged conditions. The buttering deposit with $\mathrm{Ni}-\mathrm{Fe}$ buffer layer could be the better choice for DMW joints requirements.
\end{abstract}

KEY WORDS: Dissimilar welds; Buttering; Carbon diffusion; Buffer layer; Metallurgical properties

\section{Introduction}

Dissimilar metal welds (DMWs) are required to connect the SA508Gr.3Cl.1 ferritic steel pressure vessel nozzle with SS304LN austenitic stainless steel piping. The buttering/welding is carried out more often with Inconel 82/182 (AWS A5.14-ERNiCr-3/A5.11-ENiCrFe-3) filler

Available online at http://link.springer.com/journal/40195

Dinesh W. Rathod

dineshvrathod@gmail.com

1 Department of Mechanical Engineering, Indian Institute of Technology Delhi, Hauz-Khas, New Delhi 110016, India

2 School of MACE, University of Manchester, Manchester M13 9PL, UK

3 Bhabha Atomic Research Centre, Mumbai 400085, India metals. Material compatibility with respect to physical and chemical properties is an important concern during dissimilar metal welding. Hence, Inconel 82 is often deposited on SA508Gr.3Cl.1 ferritic steel as buttering. Several failures owing to leaks and cracks in such DMW joints at various nuclear plant sites have been reported worldwide [1]. The carbon-depleted soft zone and carbon-enriched hard zone formation owing to carbon migration [2-10] is the major cause of premature failures in DMW joints $[3,10,11]$. For integrity assessment of such DMW joints, buttering deposit exhibits very important role. In DMW joints, buttering is the adjacent region to the ferritic steel that directly fuses with ferritic steel and may have a severe effect on metallurgical properties in the buttering region than that of weld metal [10]. This signifies the judicious selection of filler metal for buttering in terms of graded composition [12] of buttering material. Ni-based filler metals reduce the diffusivity of carbon $[3,6,8,9,13]$ but 
cannot completely prevent the carbon migration. The higher content of chromium $(\mathrm{Cr})$ in Inconel 82 buttering can cause carbon migration because of its higher affinity towards carbon. Hence, SA508Gr.3Cl.1 ferritic steel used as substrate for the investigation of a buttering deposit with and without buffer layer of $\mathrm{Ni}-\mathrm{Fe}$ alloy along with buttering deposition of Inconel 82. The Ni-Fe alloy (AWS A5.15, ERNiFe-CI) buffer layer reduces the composition gradient and carbon migration by splitting the material zone into two locations of buffer layer and subsequent Inconel 82 buttering layer from ferritic steel $[10,14]$.

The Ni-Fe alloy was used as an intermediate buffer layer to address the effect of carbon migration from ferritic steel owing to the absence of $\mathrm{Cr}$ in buffer layer. Dilution of filler metals with base metal causes the distinctive variations in weld metal [15]. Hence, number of effective buttering layers is also required to be quantified. The mechanical properties of DMW joints $[4,5,7,9,16]$ were investigated extensively, but the buttering and its interfacial regions in terms of specific metallurgical investigation have not been investigated in detail. It is observed from the previous investigations on DMW joints that lower tensile properties exist in the buttering region compared to that of the weld metal $[16,17]$ due to metallurgical deterioration and diffusion mechanisms in buttering region which is adjacent to the ferritic steel. Therefore, the investigation has been carried out to identify the effects of a Ni-Fe alloy buffer layer in terms of an effective number of buttering layers, thickness for selection of optimum buttering deposits required for DMW joints. The metallurgical properties were measured and analysed using electron probe microanalyser (EPMA), optical emission spectrometer (OES), martensite formation at fusion interfaces, micro-hardness across the interfaces, microstructure evolution and the carbon diffusion study. The effect of stress relief post-weld heat treatment (PWHT) and thermal ageing on buttering deposits has been taken in to account prior to the optimization.

\section{Materials and Methods}

The quenched and tempered SA508Gr.3Cl.1 ferritic steel was used as a substrate in $(150 \mathrm{~mm} \times 50 \mathrm{~mm} \times 15 \mathrm{~mm})$ plate form. The Ni-Fe alloy (ERNiFe-CI) 2.4-mm-diameter consumable was used for the intermediate buffer layer, and Inconel 82 (ERNiCr-3) was used for subsequent deposition. The chemical composition of base metal (as-received) ferritic steel and filler metals are given in Table 1. The substrates were deposited with four layers to quantify the numbers of effective buttering layers in order to optimize buttering deposits. Four layers of buttering deposit with $\sim 6 \mathrm{~mm}$ thickness are required for the effectiveness of buttering in terms of carbon migration $[10,14]$. Two weld pads were prepared with and without intermediate $\mathrm{Ni}-\mathrm{Fe}$ alloy buffer layer by employing four buttering layers in all.

Figure 1a shows the schematics of the weld pad consisting of four buttering layers of Inconel 82 without depositing a buffer layer. The schematics of the weld pad with first buffer layer and subsequent buttering layers of Inconel 82 are shown in Fig. 1b.

The deposition of buttering layers was made with manual gas tungsten arc welding (GTAW) process using 3-mm-diameter tungsten electrode and straight polarity. The weaving beads were adopted for consistent dilution in multi-pass buttering layers over a span of 50-mm-wide and 150-mm-long substrate with $10 \mathrm{~L} / \mathrm{min}$ argon gas shielding. The process parameters during buttering deposition of weld pads using buffer layer and without buffer layer are given in Table 2.

Two weld pads of four layers (in all) were equally cut in three sections of $50 \mathrm{~mm}$ each. One section was in as-buttered (as-welded) condition, while other two have been thermally aged at 330 and $450{ }^{\circ} \mathrm{C}$ for $240 \mathrm{~h}$. The effects of the operating temperature $\left(310-330^{\circ} \mathrm{C}\right)$ and accelerated condition required to be investigated for carbon migration. Therefore, thermal ageing was conducted at 330 and $450{ }^{\circ} \mathrm{C}$ for $240 \mathrm{~h}$. Such buttering deposits are often associated with stress relief PWHT at $610{ }^{\circ} \mathrm{C}$ for $1.5 \mathrm{~h}$; therefore, a 10-mm-wide cross section from as-buttered condition was extracted for PWHT.

The test specimens were extracted from both weld pads in as-buttered, thermally aged and PWHT condition for EPMA, OES, optical microscopy and micro-hardness. The chemical composition in buttering layers obtained with ARC-MET 8000 OES and the results were confirmed using EPMA (CAMECA-SX-100) chemical analysis. The validation and confirmation of OES results using EPMA analysis are given in Table 3 .

The data obtained from OES are in good agreement with EPMA and can be used for investigation with reasonable accuracy. Chemical analysis across the interfaces (dissimilar metal welds) has been obtained using EPMA. The EPMA traces were recorded from ferritic steel heat-affected zone (HAZ) to the first buttering layer (Inconel 82) with an interval of $5 \mu \mathrm{m}$ for length of $300 \mu \mathrm{m}$.

The backscatter electron (BSE) image in Fig. 2a shows the EPMA traces from HAZ ferritic steel to first buttering layer on the weld pad (four buttering layers) without buffer layer. Similarly, the EPMA traces from HAZ ferritic steel through the intermediate buffer layer (Ni-Fe alloy) to first buttering layer (2nd layer in all) of Inconel 82 have been recorded with interval of $15 \mu \mathrm{m}$ for a length of $1300 \mu \mathrm{m}$. The BSE image for EPMA traces in weld pad with buffer layer is shown in Fig. 2b. The microstructure evolution was conducted using $2 \%$ Nital for ferritic steel while $10 \%$ 
Table 1 Chemical composition of as-received base metal and filler metals

\begin{tabular}{llrrrrr}
\hline Base metal and filler metals & \multicolumn{2}{l}{ Elemental composition (wt\%) } & & & \\
\cline { 2 - 7 } & $\mathrm{C}$ & $\mathrm{Cr}$ & $\mathrm{Ni}$ & $\mathrm{Fe}$ & $\mathrm{Mn}$ & $\mathrm{Nb}$ \\
\hline SA508Gr.3Cl.1-base metal & 0.197 & 0.12 & 0.53 & 96.95 & 1.30 & - \\
Ni-Fe alloy-ERNiFe-CI & 0.025 & 0.01 & 53.01 & 43.24 & 0.73 & - \\
Inconel 82-ERNiCr-3 & 0.022 & 21.88 & 71.25 & 1.52 & 2.86 & 2.45 \\
\hline
\end{tabular}

A SA508Gr.3Cl.1 substrate without buffer layer

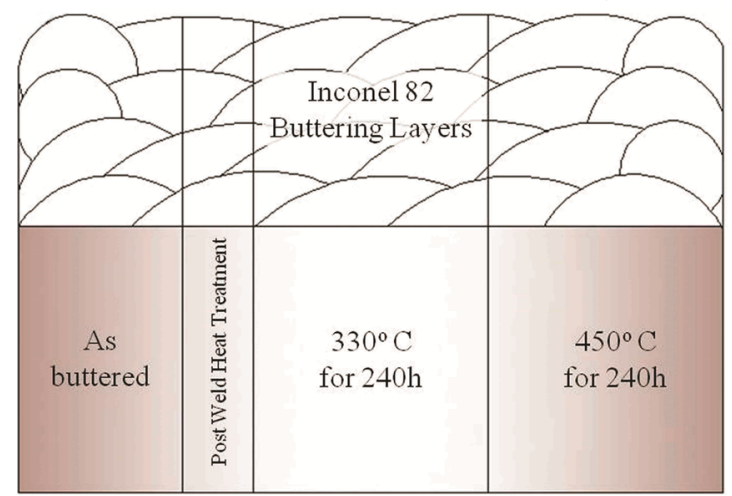

B SA508Gr.3Cl.1 substrate with buffer layer

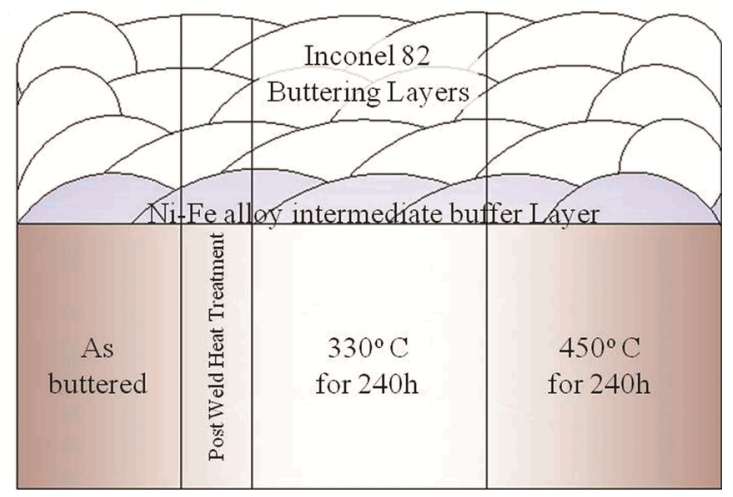

Fig. 1 Schematic of weld pads of SA508Gr3Cl.1 substrate a without buffer layer and b with buffer layer

Table 2 Process parameters for buttering deposition with and without buffer layer

\begin{tabular}{lllllll}
\hline Weld pads & Filler metal & Layers & Current (A) & Voltage (V) & Layer thickness avg. (mm) & Heat input (KJ/mm) \\
\hline Without buffer layer & Inconel 82 & 1st & 95 & $9-11$ & 2.0 & $1.64-1.74$ \\
& & 2nd & & & 1.4 & $1.66-1.72$ \\
& & 3 rd & & & 1.3 & $1.62-1.72$ \\
With buffer layer & Ni-Fe alloy & 1st & 100 & $9-11$ & 1.5 & $1.66-1.70$ \\
& Inconel 82 & 2nd & 95 & $9-11$ & 1.3 & $1.80-1.94$ \\
& & 3rd & & & 1.6 & $1.64-1.70$ \\
& & 4th & & & 2.0 & $1.62-1.70$ \\
\end{tabular}

ammonium persulphate solution was used with electrolyte etch at $6 \mathrm{~V}(60 \mathrm{~s})$ for Ni-base buttering/buffer layers. The hardness variations in weld regions and across the interfaces were measured using Leica VMHT Auto with 100 and 10 gf test loads.

\section{Results and Discussion}

\subsection{Chemical Analysis and Carbon Diffusion}

Chemical composition in four-layer weld pads with and without buffer layers is given in Table 4 for as-buttered and thermally aged conditions. Minor variations have been noticed with major alloying elements and certainly not due to thermal ageing because the substitutional diffusion is not possible at these temperatures. Diffusivity of carbon (D) has been calculated for the both weld pads using the recorded data (time and temperature) during buttering and the results obtained from OES. Diffusion coefficient $(D)$ of carbon has been estimated from ferritic steel to first layer and thereafter from third layer to fourth layer. The calculated diffusivity of carbon $(D)$ for weld pads with and without buffer layer in the as-buttered and thermally aged condition is shown in Table 5 .

The carbon diffusion coefficient $(D)$ was observed to be more in case of as-buttered condition compared to the thermally aged condition. The diffusion coefficient $(D)$ also 
Table 3 Chemical composition obtained from OES results confirmed by EPMA analysis

\begin{tabular}{|c|c|c|c|c|c|c|}
\hline \multirow[t]{2}{*}{ Specimen } & \multicolumn{5}{|c|}{ EPMA (wt\%) } & \multirow{2}{*}{$\begin{array}{l}\text { Optical emission } \\
\text { spectrometer (OES) (wt } \%)\end{array}$} \\
\hline & Element & Pt 1 & Pt 2 & Pt 3 & Avg. & \\
\hline \multirow[t]{5}{*}{ Without buffer layer (on surface of fourth layer) } & $\mathrm{C}$ & - & - & - & - & 0.011 \\
\hline & $\mathrm{Cr}$ & 21.85 & 22.00 & 22.09 & 21.98 & 21.80 \\
\hline & $\mathrm{Ni}$ & 70.04 & 69.02 & 70.07 & 69.71 & 71.85 \\
\hline & $\mathrm{Fe}$ & 1.57 & 1.55 & 1.73 & 1.62 & 1.65 \\
\hline & $\mathrm{Nb}$ & 1.55 & 2.33 & 1.67 & 1.85 & 1.84 \\
\hline \multirow[t]{5}{*}{ With buffer layer (on surface of fourth layer) } & $\mathrm{C}$ & - & - & - & - & 0.020 \\
\hline & $\mathrm{Cr}$ & 21.98 & 21.01 & 20.99 & 21.33 & 21.50 \\
\hline & $\mathrm{Ni}$ & 69.97 & 69.46 & 69.26 & 69.56 & 70.79 \\
\hline & $\mathrm{Fe}$ & 1.52 & 1.38 & 1.42 & 1.44 & 1.83 \\
\hline & $\mathrm{Nb}$ & 2.11 & 2.31 & 2.25 & 2.22 & 2.00 \\
\hline
\end{tabular}
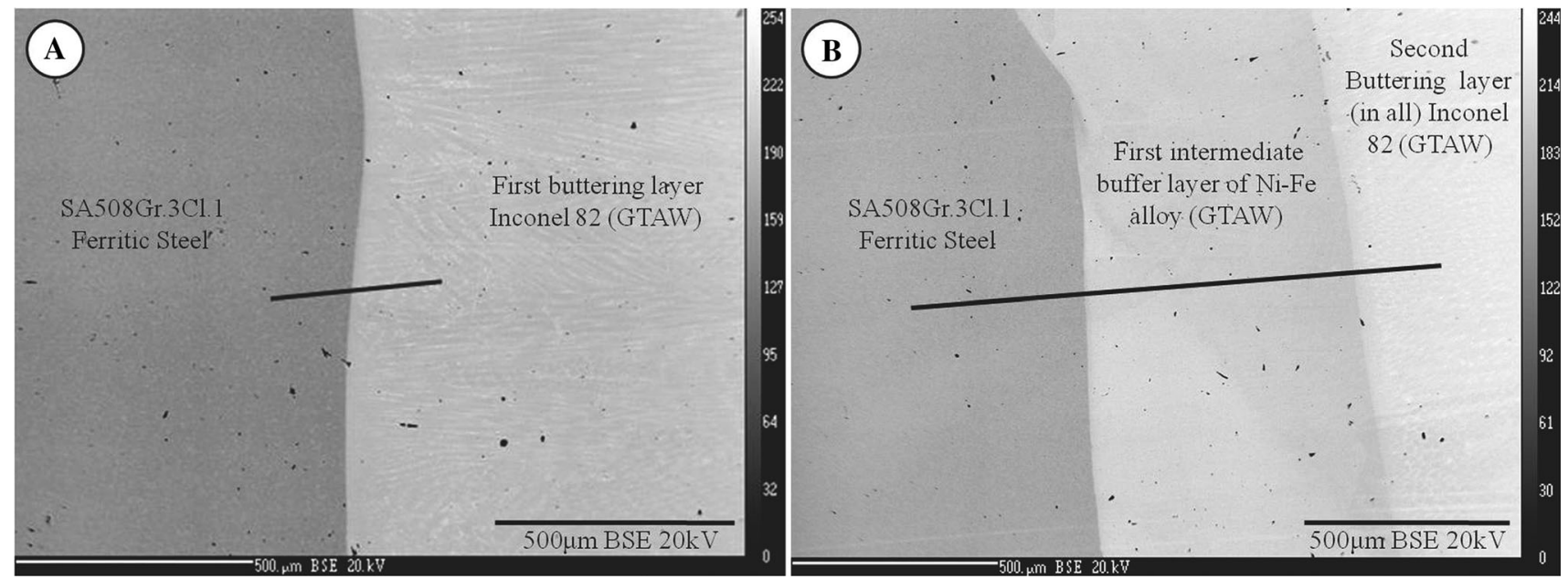

Fig. 2 BSE images of EPMA traces across the interfaces of weld pads a without buffer layer and $\mathbf{b}$ with buffer layer

observed to be considerably less in weld pads with the buffer layer compared to that of weld pads without buffer layer. The instances of uphill diffusion have been noticed with buffer layer, but due to limitation of carbon diffusion study for present work, this is described as inverse $(\uparrow)$ diffusion in the study. This indicates the migration of carbon in opposite direction, which is from fourth layer to third layer.

Dilution effects are significant in first layer (buttering/ buffer) of buttering owing to the mixing with ferritic steel substrate. The transition region exists between buttering and substrate. The narrow transition region has distinctly different microstructure and properties from adjacent regions [18]. An effect of dilution is not prevalent in fourth buttering layer of both weld pads [19] as the filler metal chemistry confirms in fourth layer. The carbon migration has been estimated using the reasonably accurate Groube solution for diffusion couple. Decomposition of carbide in ferritic steel and carbon migration to Inconel 82 buttering/ $\mathrm{Ni}-\mathrm{Fe}$ buffer layer takes place at the interface. The driving force for the diffusion is the activity gradient of carbon (C) between low $\mathrm{Cr} /$ high $\mathrm{C}$ (ferritic steel) and high $\mathrm{Cr} / \mathrm{low}$ $\mathrm{C}$ content (Inconel 82). In weld pad with buffer layer, $\mathrm{Ni}-$ Fe alloy resists the carbon migration because of negligible carbon activity gradient owing to the absence of $\mathrm{Cr}$. Increasing nickel content in filler metal alters the carbon solubility, makes carbide less stable, changes diffusivity and in general retards carbon migration from ferritic steel [3]. The migration of carbon leads to the formation of a decarburized soft zone in HAZ ferritic steel and hard zone in buttering adjacent to the interface. Inconel 82 buttering cannot completely prevent the formation of decarburized zone. However, Ni-Fe buffer layer remarkably controls the formation of decarburized soft zone. The higher $\mathrm{Cr}$ content in Inconel 82 acts as a driving force to support the formation of soft zone [8], whereas it is absent in Ni-Fe buffer 
Table 4 Chemical composition in fourth buttering layers for as-buttered and thermally aged conditions of weld pads with and without buffer layer

\begin{tabular}{|c|c|c|c|c|c|c|c|c|}
\hline \multirow[t]{2}{*}{ Weld pads } & \multirow[t]{2}{*}{ Condition } & \multicolumn{7}{|c|}{ Elemental composition in weight percentage } \\
\hline & & Layer & $\% \mathrm{C}$ & $\% \mathrm{Cr}$ & $\% \mathrm{Ni}$ & $\% \mathrm{Fe}$ & $\% \mathrm{Mn}$ & $\% \mathrm{Nb}$ \\
\hline \multirow{3}{*}{$\begin{array}{l}\text { Without buffer layer and buttering (Inconel 82), thermal } \\
\text { ageing for } 240 \mathrm{~h}\end{array}$} & As-buttered condition & 4th & 0.011 & 21.30 & 71.85 & 1.86 & 1.91 & 1.84 \\
\hline & $330^{\circ} \mathrm{C}$ thermally aged & 4 th & 0.014 & 21.17 & 72.20 & 1.90 & 1.91 & 1.92 \\
\hline & $450^{\circ} \mathrm{C}$ thermally aged & 4 th & 0.014 & 21.00 & 71.81 & 1.78 & 1.98 & 2.08 \\
\hline \multirow{3}{*}{$\begin{array}{l}\text { With buffer layer (Ni-Fe alloy) and buttering (Inconel 82), } \\
\text { thermal ageing for } 240 \mathrm{~h}\end{array}$} & As-buttered condition & 4th & 0.020 & 21.50 & 71.79 & 1.83 & 1.83 & 2.00 \\
\hline & $330^{\circ} \mathrm{C}$ thermally aged & 4th & 0.022 & 21.21 & 71.95 & 1.91 & 1.77 & 1.81 \\
\hline & $450^{\circ} \mathrm{C}$ thermally aged & 4th & 0.022 & 21.31 & 72.17 & 1.89 & 2.01 & 2.06 \\
\hline
\end{tabular}

Table 5 Diffusivity of carbon $(D)$ in buttering layers for as-buttered and thermally aged conditions of weld pads with and without buffer layer

\begin{tabular}{|c|c|c|c|c|}
\hline \multirow[t]{2}{*}{ Weld Pads } & \multirow[t]{2}{*}{ Layer description } & \multicolumn{3}{|c|}{ Diffusivity $(D)$ in $\mathrm{m}^{2} / \mathrm{s}$} \\
\hline & & As-buttered & $330^{\circ} \mathrm{C}$ aged & $450{ }^{\circ} \mathrm{C}$ aged \\
\hline \multirow[t]{2}{*}{ Without buffer layer (Inconel 82) } & $\begin{array}{l}\text { Ferritic steel-first layer } \\
\text { (SA508Gr3.Cl.1-Inconel 82) }\end{array}$ & $2.13 \times 10^{-10}$ & $4.55 \times 10^{-13}$ & $4.55 \times 10^{-13}$ \\
\hline & $\begin{array}{l}\text { Third layer-fourth layer } \\
\text { (Inconel 82-Inconel 82) }\end{array}$ & $1.64 \times 10^{-11}$ & $1.63 \times 10^{-12}$ & $1.63 \times 10^{-12}$ \\
\hline \multirow[t]{2}{*}{ With buffer layer (Ni-Fe alloy-Inconel 82) } & $\begin{array}{l}\text { Ferritic steel-first buffer layer } \\
\text { (SA508Gr3.Cl.1-Ni-Fe alloy) }\end{array}$ & $3.24 \times 10^{-11}$ & $6.24 \times 10^{-13}$ & $2.22 \times 10^{-12}$ \\
\hline & $\begin{array}{l}\text { Third layer-fourth layer } \\
\text { (Inconel 82-Inconel 82) }\end{array}$ & $\uparrow 4.46 \times 10^{-9}$ & $1.55 \times 10^{-13}$ & $1.55 \times 10^{-13}$ \\
\hline
\end{tabular}

$\uparrow$ Indicates inverse diffusion

layer. Hence, the absence of $\mathrm{Cr}$ in buffer layer leads to negligible driving force for carbon migration.

The carbon diffusion coefficient $(D)$ estimated with Groube solution using Eq. (1).

$C_{(x, t)}-C_{1}=\frac{C_{2}-C_{1}}{2}\left[1-\operatorname{erf}\left(\frac{x}{2 \sqrt{D t}}\right)\right]$,

where $C_{(x, t)}$ is the known weight percentage of carbon, $C_{2}$ is the higher concentration of carbon, $C_{1}$ is the lower concentration of carbon. $D$ represents the diffusivity of carbon in $\mathrm{m}^{2} / \mathrm{s}, x$ is the distance in metre at which measurement made and $t$ is the time in seconds. The estimation of diffusion coefficient has been made in accordance with the earlier study of Rathod et al. [10]. The temperature in HAZ of ferritic steel was measured during buttering deposition, and it was more than $450{ }^{\circ} \mathrm{C}$ for $42 \mathrm{~min}$. This time $t$ was used for calculating the carbon diffusion coefficient in as-buttered condition. The time of $240 \mathrm{~h}$ was used in calculation of diffusivities in aged conditions. The estimated diffusivities are listed in Table 5.

Carbon diffusivity is more in as-buttered condition than the aged condition because of dilution, solid and liquid diffusion. Carbon diffusion in solid state has been also measured for aged conditions. Owing to the absence of $\mathrm{Cr}$ in Ni-Fe alloy buffer layer, the diffusivity is considerably less than weld pad without buffer layer. The inverse diffusivity $(\uparrow)$ evidenced in fourth layer of weld pad with buffer layer and that indicates no further carbon migration can exist from fourth layer. The diffusivity of weld pad with buffer layer has been compared with the diffusivities reported by Rathod et al. [10] for weld pad with buffer layer and subsequent buttering with GMAW process. The diffusivities in fourth layer [10] have been more favourable than the diffusivities estimated in the present work for both weld pads.

\subsection{Martensite Formation at Fusion Boundaries}

The specimens from as-buttered condition of both weld pads were analysed for chemical analysis using EPMA (Fig. 2). The major alloying element variations using EPMA for fusion boundaries and OES at subsequent layers are shown in Figs. 3 and 4 for the weld pads without and with buffer layer, respectively. During buttering 
deposition, filler metal diluted with substrate (SA508Gr.3Cl.1 ferritic steel) and partially mixed zone (PMZ) exhibits at the fusion interface. Due to variation in nominal composition between substrate and the weld deposit (cladding or buttering), a composition gradient exists within the PMZ [13]. The sharp composition gradient within PMZ and in first layer (buttering) can be observed in Fig. 3. This sharp composition gradient split into two material zones owing to use of Ni-Fe alloy buffer layer as shown in Fig. 4.

The major alloying elements $\mathrm{Cr}$, $\mathrm{Ni}$ and $\mathrm{Fe}$ were measured using EPMA. The concentration of light element (carbon C) and low-concentration elements $\mathrm{Mn}$ and Mo have been estimated by considering the dilution of major alloying elements $\mathrm{Cr}, \mathrm{Fe}$ and $\mathrm{Ni}$ across the interfaces using EPMA [13, 20-22]. Variation in dilution of $\mathrm{Cr}, \mathrm{Ni}$ and $\mathrm{Fe}$ has been used along with nominal concentration of elements in ferritic steel and filler metals to estimate the lightand low-concentration elements by back calculations $[13,20-22]$. It is assumed that light- and low-concentration elements mixed in the same proportion as major element $\mathrm{Cr}$, Ni and $\mathrm{Fe}$ were diluted. A variation in dilution was estimated by Eq. (2) with the help of EPMA trace data from Figs. 3 and 4.

$D_{1}=C_{\mathrm{PMZ}}-C_{\mathrm{FM}} / C_{\mathrm{BM}}-C_{\mathrm{FM}}$,

where $D_{1}$ indicates dilution, $C_{\mathrm{PMZ}}$ is the concentration of elements in PMZ, $C_{\mathrm{FM}}$ and $C_{\mathrm{BM}}$ indicate the nominal concentration of elements in filler metals and base metal, respectively. The $C_{\mathrm{FM}}$ and $C_{\mathrm{BM}}$ values of major elements have measured by OES. $C_{\mathrm{PMZ}}$ values of elements obtained from the EPMA data given in Figs. 3 and 4. The percentage dilution $\left(D_{1}\right)$ in PMZ from OES and EPMA at each position of major elements $\mathrm{Cr}, \mathrm{Ni}$ and $\mathrm{Fe}$ is shown in
Fig. 5a, b for weld pads without and with buffer layer of $\mathrm{Ni}-\mathrm{Fe}$ alloy, respectively.

The values of light element and low-concentration elements were estimated using Eq. (3).

$C_{\mathrm{PMZ}}=D_{\mathrm{l}} C_{\mathrm{BM}}+\left(1-D_{1}\right) C_{\mathrm{FM}}$.

The estimated values of elements for $C_{\mathrm{PMZ}}$ have been accounted for in the estimation of martensite formation within the PMZ. Considerably more dilution has been observed with buffer layer $(\mathrm{Ni}-\mathrm{Fe})$ in Fig. $5 b$ than the buttering (Inconel 82) layer in Fig. 5a. The dilution in Inconel 82 buttering is observed to be almost same in both weld pads with and without buffer layer.

The ferritic steel was acted as substrate for the first layer of Inconel 82 and Ni-Fe alloy, while the weld pad with buffer layer, the first buffer layer (diluted $\mathrm{Ni}-\mathrm{Fe}$ alloy layer), acts as a substrate for deposition of the second layer of buttering (Inconel 82). Composition chemistry gets changed in PMZ and in weld deposit due to mixing (dilution) between filler metal and substrate; therefore, resulting composition may form the martensite during weld cooling. The calculations of martensite start $\left(M_{\mathrm{s}}\right)$ temperature as per Gooch and Dupont [13, 20-22] were made using Eq. (4).

$$
\begin{gathered}
M_{\mathrm{s}}\left({ }^{\circ} \mathrm{C}\right)=540-(497 \mathrm{C} \%+6.3 \mathrm{Mn} \%+36.3 \mathrm{Ni} \% \\
+10.8 \mathrm{Cr} \%+46.6 \mathrm{Mo} \%) .
\end{gathered}
$$

The variation in maximum and minimum martensite start $\left(M_{\mathrm{s}}\right)$ temperature in $\mathrm{PMZ}$ with estimated martensite thickness across the interface without buffer layer is shown in Fig. 6a. Similarly, the $M_{\mathrm{s}}$ temperature and martensite thickness across the interfaces with buffer layer are shown in Fig. 6b. The $\sim 2-\mu$ m-thick martensite layer has been estimated with Inconel 82 layer while $\sim 6-\mu \mathrm{m}$-thick

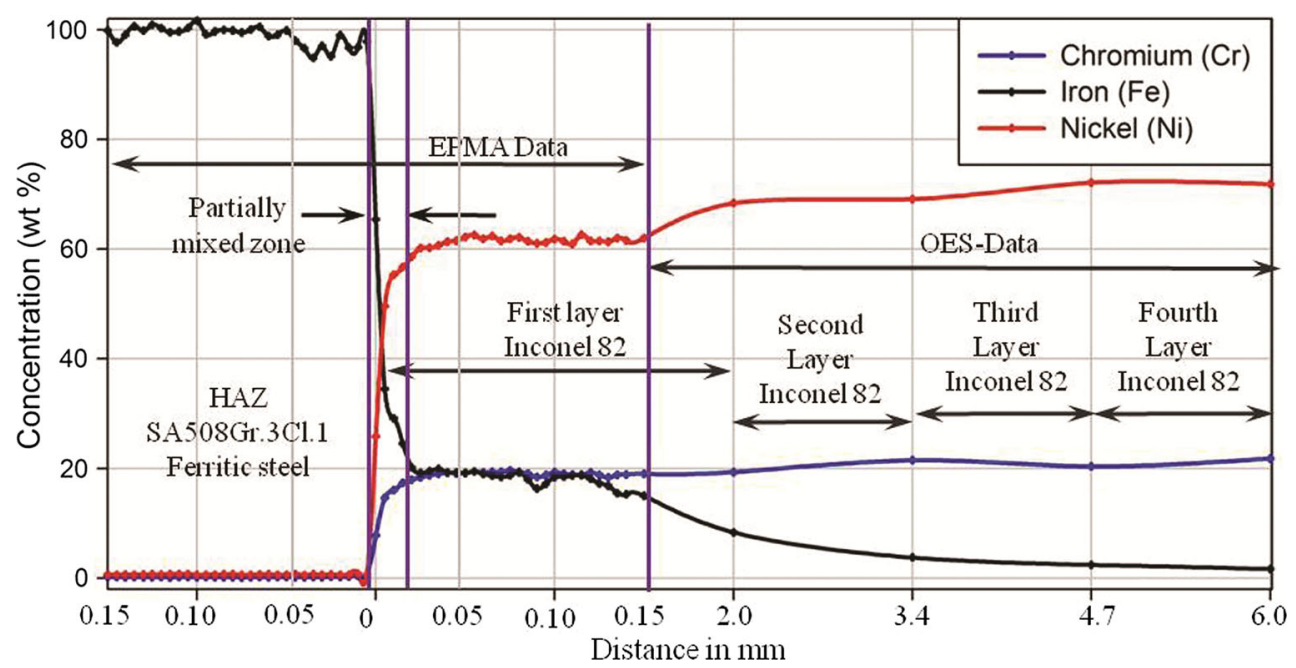

Fig. 3 Major alloying element variations by EPMA across interface and OES at subsequent layers for weld pad without buffer layer 


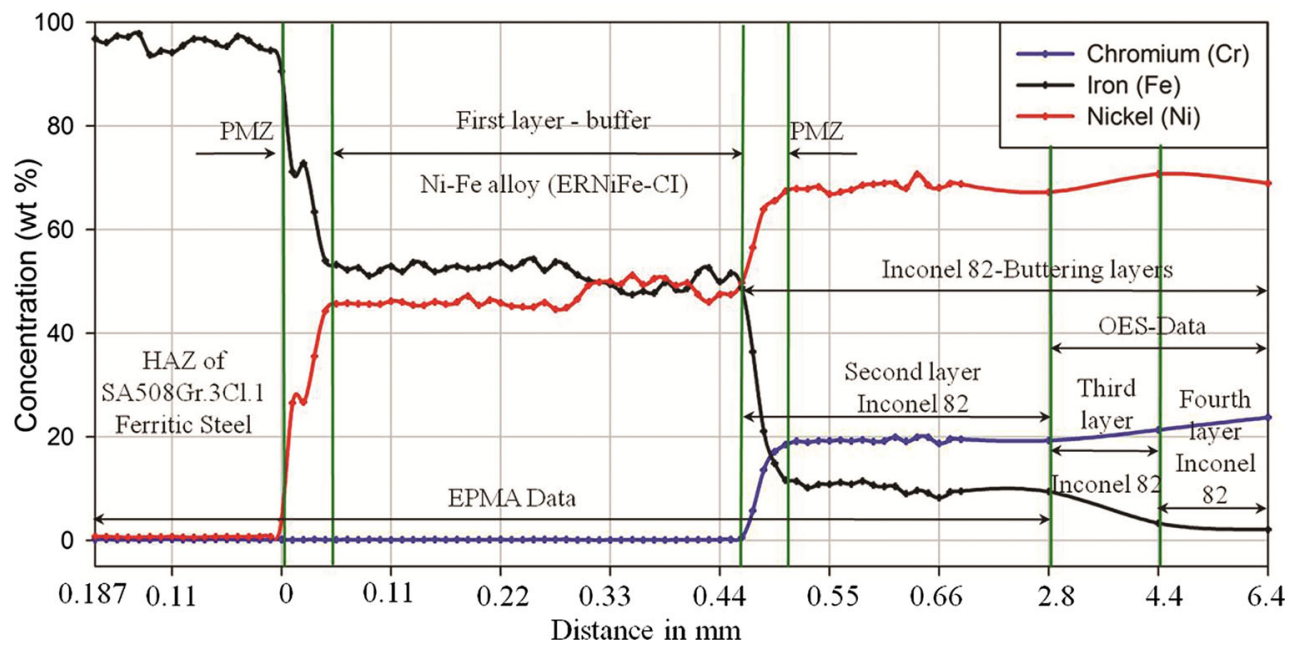

Fig. 4 Major alloying element variations by EPMA across interfaces and OES at subsequent layers for weld pad with buffer layer
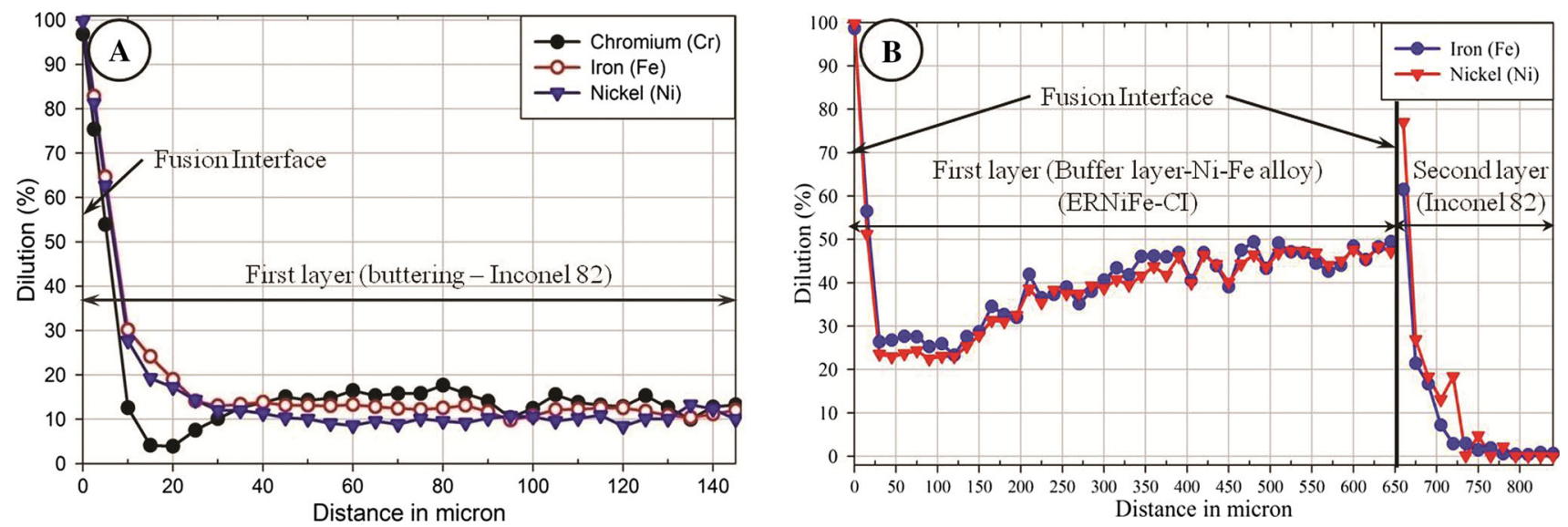

Fig. 5 Variations in dilution for major alloying elements by EPMA measurement in weld pads a without buffer layer and $\mathbf{b}$ with buffer layer

martensite layer was observed with ferritic steel and $\mathrm{Ni}-\mathrm{Fe}$ alloy buffer layer.

Elements like C, Mn, Ni, Cr and Mo [13] are actively participated in the martensite formation. Chemical composition variations within PMZ owing to dilution could increase the hardenability by martensite formation as an effect of cooling rate during solidification [3, 13, 20, 21], and these variations are noticed in Figs. 3 and 4. The composition gradient between ferritic steel and Inconel 82 is large, and it remains low due to buffer layer but splits into two locations of buffer and buttering layers. This gradient is comparatively lower using buffer layer than without buffer layer. The same instances are shown in Fig. 5a, b. Chemical composition variation within PMZ is different for both weld pads, and according to Eq. (4), the martensite thickness in PMZ of buffer layer would be more, while, in both weld pads for PMZ of Inconel 82, the martensite thickness remains same owing to chemical composition in PMZ. The estimated thickness of martensite by Rathod et al. [10] for buffer layer was $\sim 7.5 \mu \mathrm{m}$, while in present study it is $\sim 6 \mu \mathrm{m}$ because of different dilution recorded in GTAW process of this work. Similarly, for Inconel 82 , it was reported $\sim 2.5 \mu \mathrm{m}[10]$, and in present study, it is $\sim 2 \mu \mathrm{m}$. These variations are due to different dilution by GTAW and GMAW processes.

\subsection{Microstructure Evolution}

The ferritic steel microstructure is fully bainitic in as-received condition. The formation of carbon-depleted soft zone with white phase field (ferrite) in HAZ of ferritic steel using Inconel 82 (without buffer layer) is shown in Fig. 7a. The carbon-enriched zone evidenced in HAZ of ferritic steel with buffer layer and is shown in Fig. 7b.

Microstructure obtained on the specimens in as-buttered condition is shown in Fig. 7 and arrows indicate the carbon-depleted and carbon-enriched zone. The sharp fusion boundary between Inconel 82 (1st buttering layer) and 

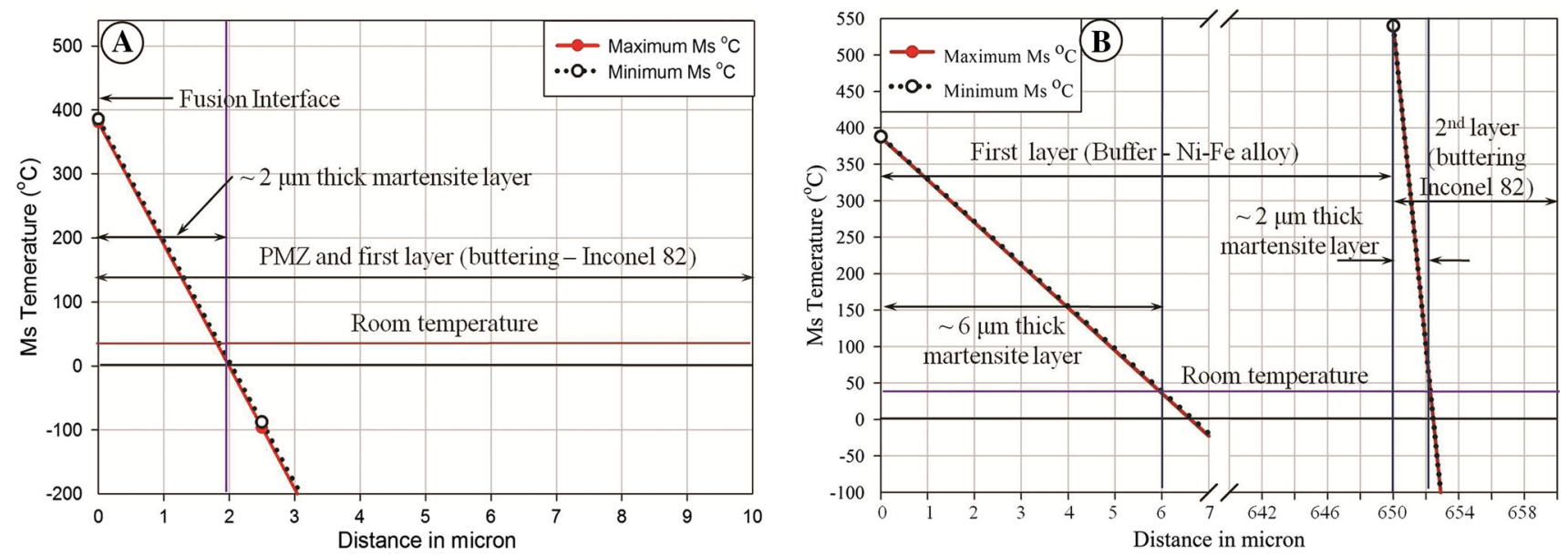

Fig. 6 Estimated martensite thickness and $M_{\mathrm{s}}$ temperature variations across the interfaces of weld pads a without buffer layer and $\mathbf{b}$ with buffer layer
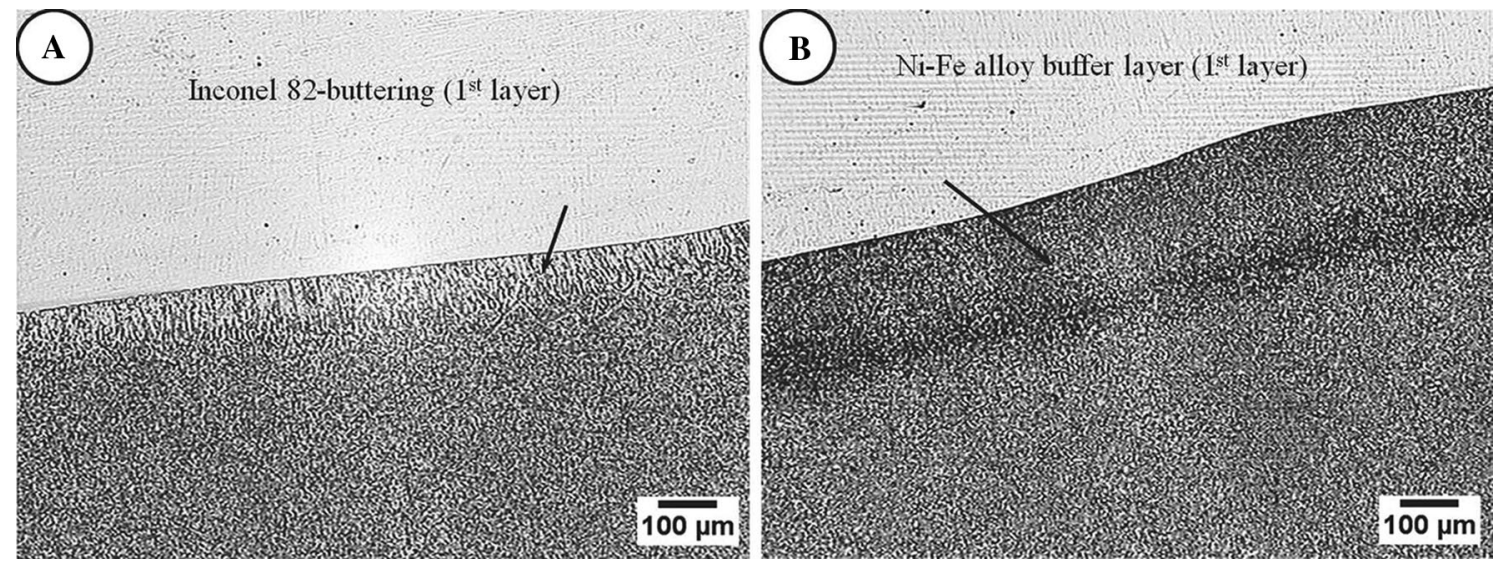

Fig. 7 Ferritic steel and first layer interface of a Inconel 82 without buffer layer and b Ni-Fe alloy buffer layer

ferritic steel is shown in Fig. 8a. The figure shows dominant ferrite (white) phase field with small fraction of pearlite in HAZ ferritic steel. Epitaxial growth at fusion boundary between $\mathrm{Ni}-\mathrm{Fe}$ alloy (1st buffer layer) and ferritic steel is shown in Fig. 8b. Coarse grain ferrite (white) exists in HAZ, but the fraction of pearlite (dark) is more than ferrite phase. The pearlite is observed in without buffer layer (owing to 1st buttering layer of Inconel 82) deposit and is shown in Fig. 8a.

Both microstructures were obtained for as-buttered condition. The effects of thermal ageing (aged at $450{ }^{\circ} \mathrm{C}$ for $240 \mathrm{~h}$ ) are shown in Fig. 9a, b. The formation of carbon-depleted zone with significant ferrite and restructuring of pearlite owing to thermal ageing is shown in Fig. 9a without buffer layer. Significant changes in microstructure have been identified in Figs. 8a and 9a. The effect of thermal ageing has also been observed in HAZ ferritic steel (with buffer layer) as shown in Figs. 8b and 9b.
Considerable restructuring of pearlite caused and formation ferrite field noticed at fusion interface owing to thermal ageing. Initial bainitic structure was observed to be absent in HAZ's of both weld pads. Carbide precipitates and laves phases at grain boundaries in Fig. 10a of Inconel 82 buttering (1st buttering layer) adjacent to ferritic steel are indicated by arrows. The undiluted ferrite in $\mathrm{Ni}-\mathrm{Fe}$ alloy buffer layer is shown in Fig. 10b and indicated with arrows. The low-carbon $\mathrm{Fe}-\mathrm{Ni}-\mathrm{C}$ system martensite is clearly evidenced in Fig. 10b owing to dilution of Ni-Fe alloy with ferritic steel and resulting weld chemistry.

Figure 11 shows the microstructure of Inconel 82 (buttering) in interior of fourth layer. The dendrite core with solidification grain boundaries (SGB) is shown in Fig. 11a in as-buttered condition. Arrows indicate the secondary phase particles and laves phases $\left(\mathrm{Fe}_{2} \mathrm{Nb}\right)$ in inter-dendritic regions. The effect of thermal ageing at $450{ }^{\circ} \mathrm{C}$ is shown in Fig. $11 b$. 

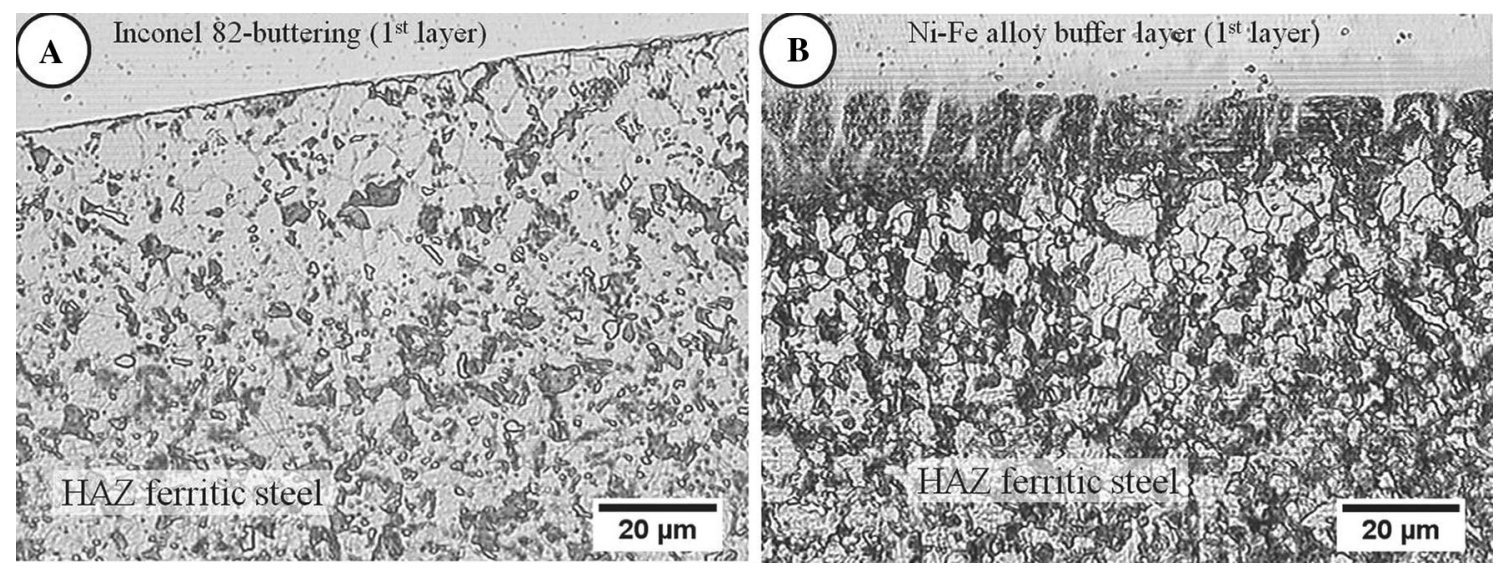

Fig. $8 \mathrm{HAZ}$ of ferritic steel near weld interface for a Inconel 82 without buffer layer and b Ni-Fe alloy buffer layer
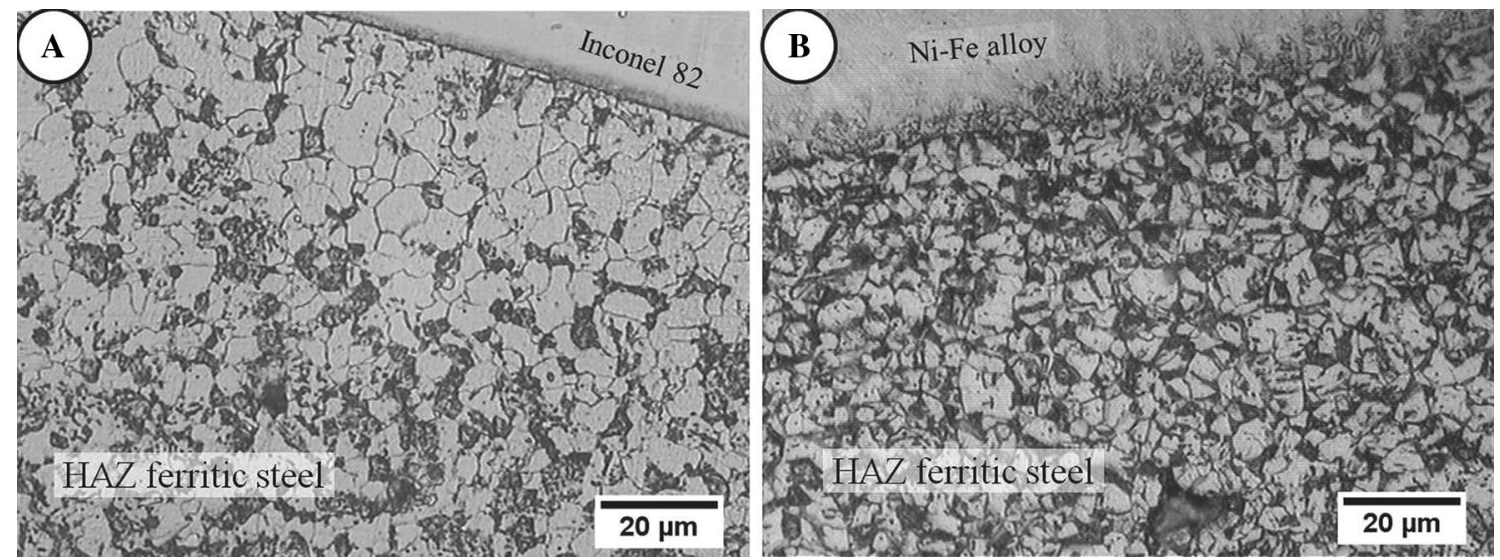

Fig. $9 \mathrm{HAZ}$ of ferritic steel at $450{ }^{\circ} \mathrm{C}$ aged condition a without buffer layer and $\mathbf{b}$ with buffer layer
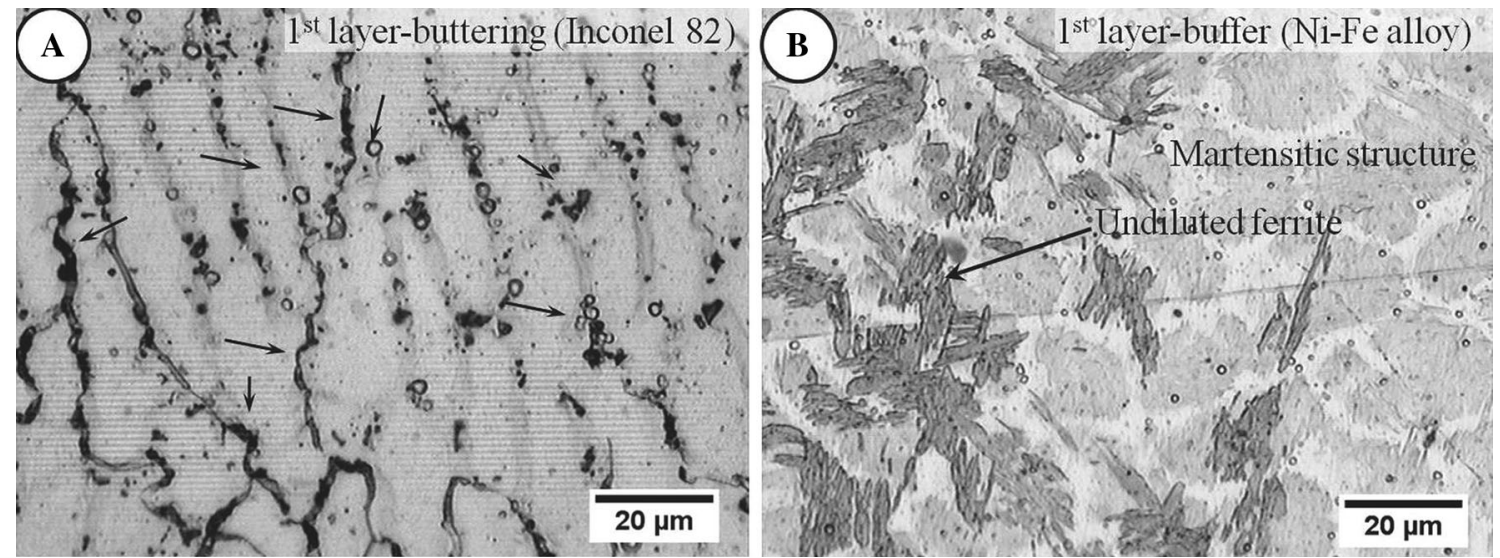

Fig. 10 Microstructure of first layer near the interface for a Inconel 82 buttering and $\mathbf{b} \mathrm{Ni}-\mathrm{Fe}$ alloy buffer layer

The fraction of laves phases (dark indicated with arrows) increased than as-buttered condition. The significantly varied microstructure of thermally aged condition $\left(450^{\circ} \mathrm{C}\right)$ than as-buttered condition is observed. The significant fraction of equiaxed dendrites is shown in Fig. 12 of Inconel 82 buttering in fourth layer with the intermediate buffer layer (1st layer of $\mathrm{Ni}-\mathrm{Fe}$ alloy).
Figure 12a shows the microstructure of Inconel 82 in asbuttered condition. The laves phases are present at grain boundaries (dark) with evidence of SGBs. Microstructure of Inconel 82 in fourth layer of thermally aged $\left(450^{\circ} \mathrm{C}\right)$ specimen is shown in Fig. 12b. The considerable changes in the dendrite arm spacing of equiaxed dendrite, size of laves phases and 

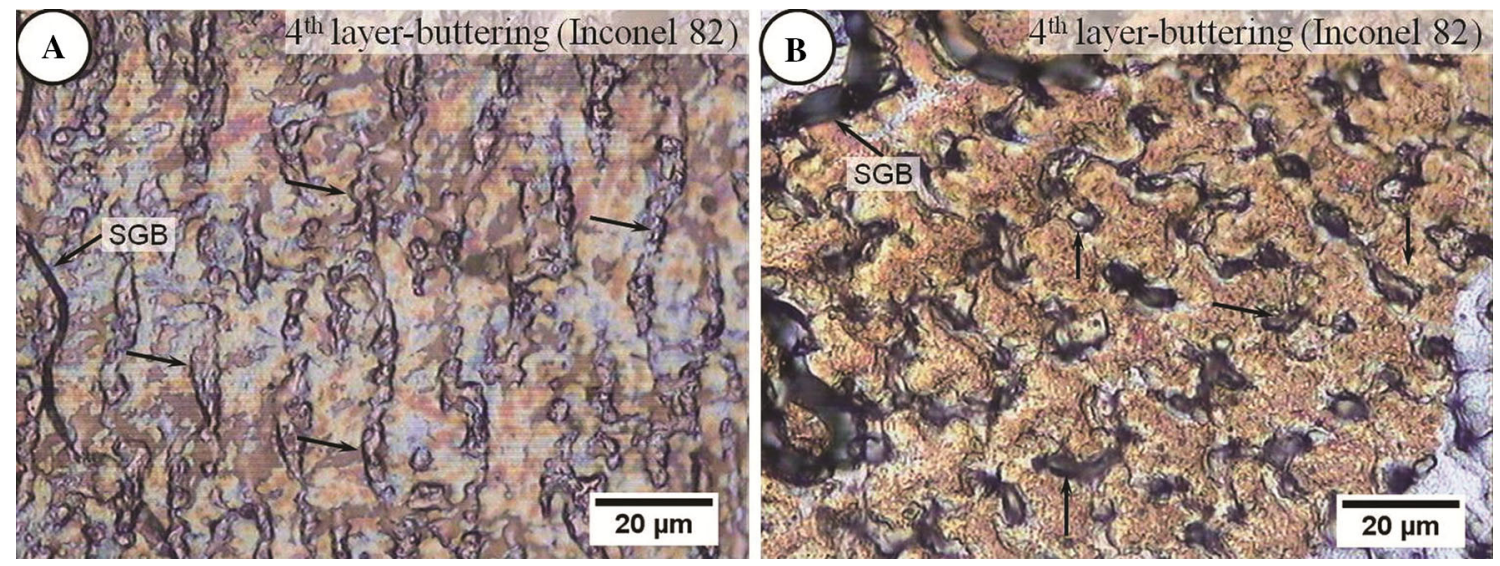

Fig. 11 Interior of buttering in fourth layer without buffer layer in a as-buttered condition and $\mathbf{b} 450{ }^{\circ} \mathrm{C}$ aged condition

SGBs are observed because of thermal ageing. There is evidence to support the significant variations owing to buffer layer (Fig. 7) in terms of carbon migration. The decarburized soft zone of ferrite field formed within the HAZ of ferritic steel due to migration of carbon for weld pad without buffer layer, while carbon-enriched zone in HAZ ferritic steel signifies the control of carbon migration because of $\mathrm{Ni}-\mathrm{Fe}$ buffer layer. The mixing of $\mathrm{Ni}$-Fe buffer layer causes the epitaxial growth but not in Inconel 82 due to resulting chemistry in deposit. The significant carbon migration due to Inconel 82 buttering also confirmed in Fig. 8. In the thermally aged condition $\left(450{ }^{\circ} \mathrm{C}\right)$, carbon migration is higher with Inconel 82 buttering due to a higher-temperature gradient and the resulting activity gradient of carbon. However, this effect is not noticed owing to Ni-Fe buffer layer as shown in Fig. 9. The filler metal (Inconel 82) chemistry in first layer has resulted in formation of less carbide precipitates and laves phases. However, undiluted ferrite with martensite structure has been formed in $\mathrm{Ni}-\mathrm{Fe}$ buffer layer because of diluted chemistry in weld deposit. These variations are shown in Fig. 10. Owing to different weld metal chemistry of both filler metals, different microstructure was resulted.
The marginal growth of laves phase in thermal ageing at $450{ }^{\circ} \mathrm{C}$ has been confirmed in (Fig. 11) fourth layer of Inconel 82 buttering without buffer layer. When buffer layer is used, the microstructure of Inconel 82 in fourth layer (Fig. 12) has been changed and can be compared with Fig. 11 without buffer layer. Filler metal chemistry in fourth buttering layer has been varied significantly due to buffer layer and has resulted in equiaxed dendrites with considerably more fraction of laves phases. Fe content would be more in buttering layers with buffer layer than without buffer layer because of dilution. This is caused to form the comparatively more fraction of laves phases $\left(\mathrm{Fe}_{2} \mathrm{Nb}\right)$ in buttering layer. The effect due to thermal ageing has been noticed in Fig. 12b of fourth layer of buttering with buffer layer. This effect is not significant for as-buttered condition as shown in Fig. 12a.

\subsection{Micro-Hardness Measurements}

The average micro-hardness $\left(\mathrm{HV}_{100}\right)$ in the HAZ ferritic steel and subsequent buffer/buttering layers for both weld pads in
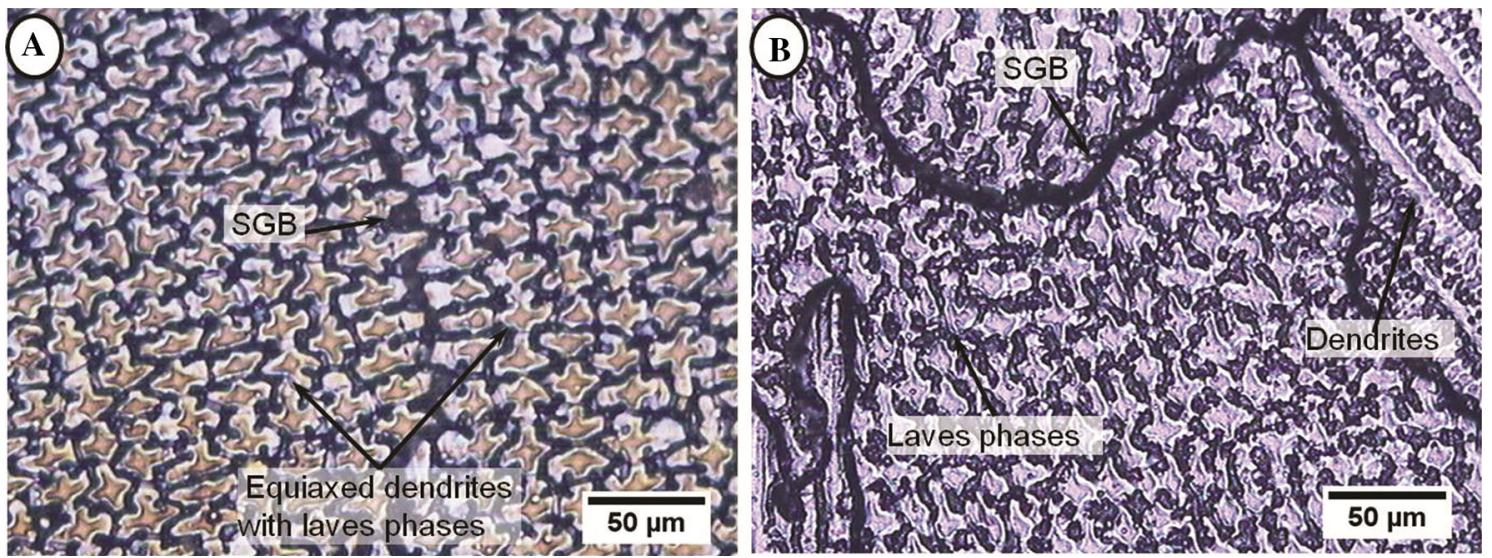

Fig. 12 Interior of buttering in fourth layer with buffer layer in a as-buttered condition and $\mathbf{b} 450{ }^{\circ} \mathrm{C}$ aged condition 


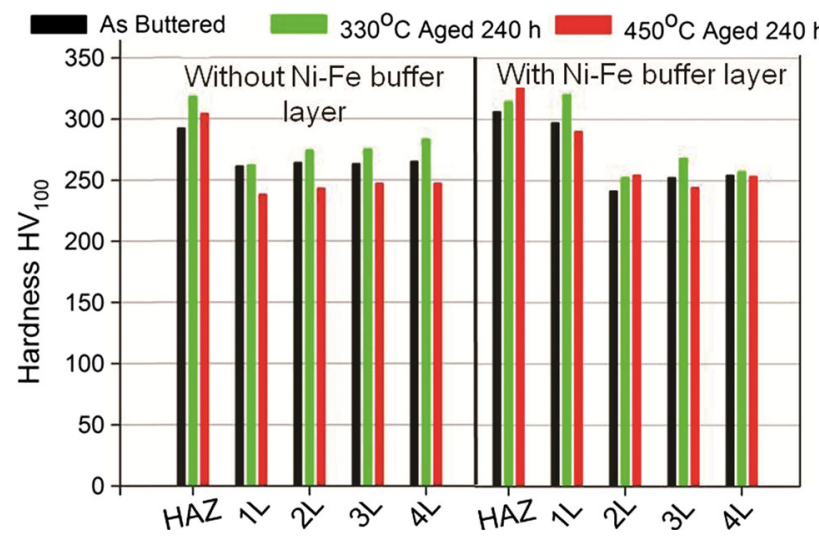

Fig. 13 Average micro-hardness in the HAZ, buttering and buffer layer of both weld pads with and without buffer layer as-buttered and thermally aged condition is given in Fig. 13. The primary austenite structure in Inconel 82 buttering does not undergo allotropic transformation during deposition and respective cooling [23]. It remains austenitic; therefore, in each layer of buttering (Inconel 82), hardness is not expected to vary $[2,7]$. The hardness in Inconel 82 buttering layers of weld pad with buffer layer is marginally less in buttering layers (Inconel 82) of weld pad without buffer layer.

Hardness across the interface of buttering and ferritic steel (without buffer layer) has been presented in Fig. 14. The peak hardness noticed at the fusion interface. Significant effects due to thermal ageing and PWHT have also been observed. Peak hardness at interface reduced in $450{ }^{\circ} \mathrm{C}$ aged and PWHT specimens. Meanwhile, for PWHT specimens, the hardness significantly decreased in

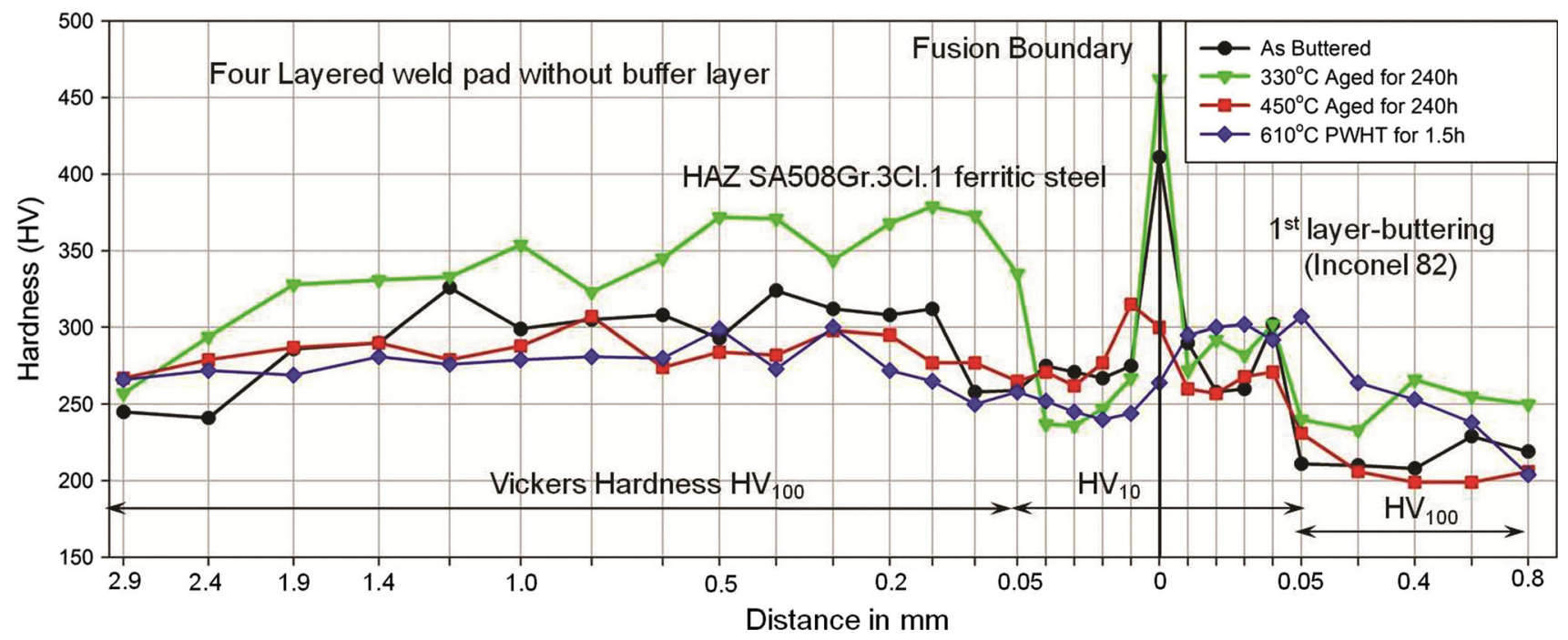

Fig. 14 Micro-hardness variations across the fusion interface of weld pad without buffer layer

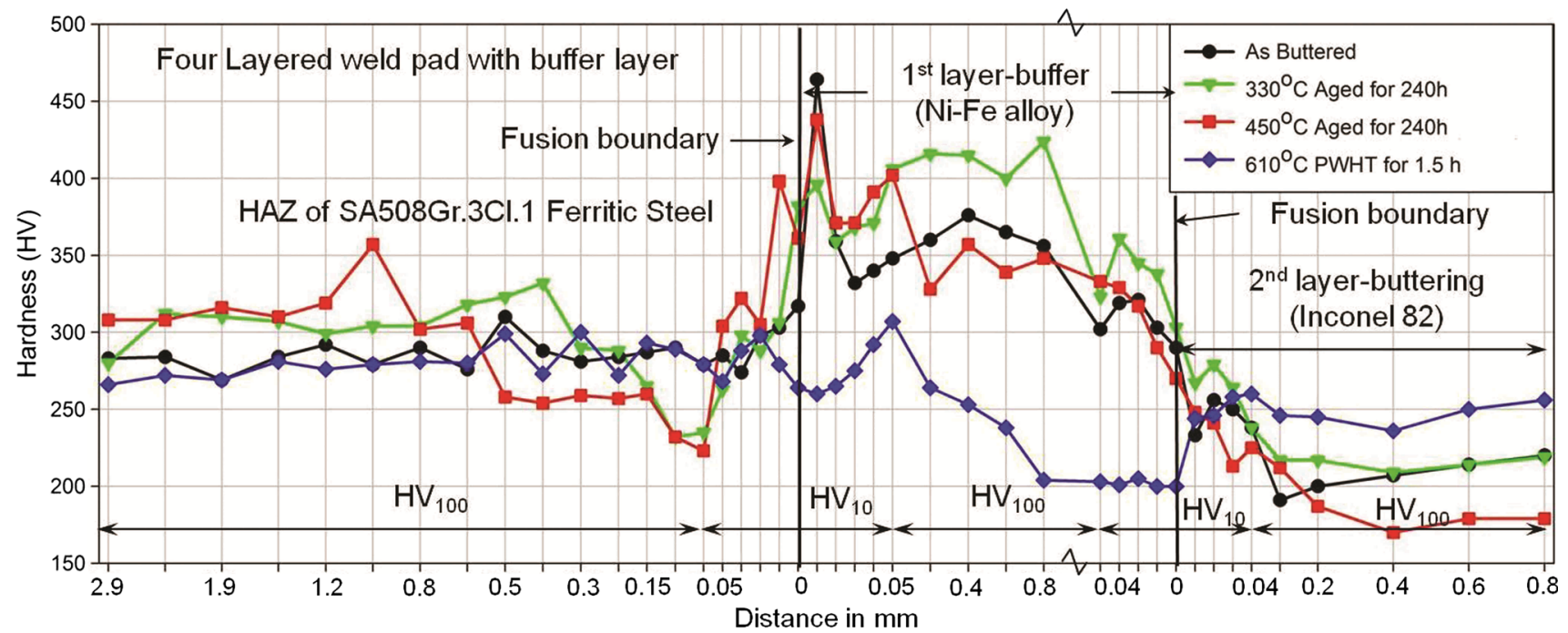

Fig. 15 Micro-hardness variations across the fusion interfaces of weld pad with buffer layer 
HAZ ferritic steel ( $\sim 50 \mu \mathrm{m}$ from interface) and increased in buttering ( $\sim 50 \mu \mathrm{m}$ from interface). Higher hardness across the interface has been observed with $330{ }^{\circ} \mathrm{C}$ thermally aged condition than others.

The micro-hardness variations across the interfaces of ferritic steel-Ni-Fe buffer layer-Inconel 82 buttering for the weld pad with buffer layers are shown in Fig. 15. Peak hardness was noticed in buffer layer near the ferritic steel interface. Considerable variations were caused due to thermal ageing and PWHT. The increased hardness (due to martensite) is reduced significantly in the PWHT specimen, and such variations are shown in Fig. 15.

The faster cooling rate and resulting thermodynamic transformation in HAZ of ferritic steel could form fraction of reformed martensite $[24,25]$ and increase the hardness in HAZ. The average hardness in HAZ of ferritic steel with buffer layer is marginally higher due to the saturation of carbon in HAZ compared to the HAZ without buffer layer.

The resulting chemistry in buffer layer and subsequently deposited buttering layer could have marginally more content of Fe and the very less carbon content. Hence, the Fe$\mathrm{Ni}-\mathrm{C}$ martensite (Fig. 10b) formed in buffer layer has the higher hardness than buttering layer. The martensite hardness is reduced with thermal ageing at $450{ }^{\circ} \mathrm{C}$. Therefore, the hardness in buttering without buffer layer is marginally higher $\left(20-30 \mathrm{HV}_{100}\right)$ than the buttering layer with buffer layer. The specimens aged at $330{ }^{\circ} \mathrm{C}$ (operating temperature) have been observed with marginally increased hardness $\left(20-30 \mathrm{HV}_{100}\right)$ than the as-buttered condition due to ageing effect on phase fields in buttering layers and buffer layer of the both conditions (with and without buffer layer specimens) [10]. No tempering effect on phases for reduction in hardness evidenced. Reduction in hardness $\left(40-50 \mathrm{HV}_{100}\right)$ in $\mathrm{HAZ}$ of ferritic steel (50- $\mu \mathrm{m}$ distance from the interface) exists owing to decarburized soft zone (Fig. 14 of without buffer layer). However, such reduction was not evidenced in weld pad with buffer layer (Fig. 15). Hardness reduction is significant in HAZ, first buttering layer, and buffer layer due to tempering caused by PWHT which is considerably at the higher temperature of $610{ }^{\circ} \mathrm{C}$ for $90 \mathrm{~min}$ (that may cause tempering of martensite and formation of tempered martensite in the matrix). The $\mathrm{Fe}-\mathrm{Ni}-\mathrm{C}$ martensite in buffer layer was evidenced with significant tempering effect. The peak hardness at interface (due to martensite as estimated) in weld pad without buffer layer has been seen with tempering effect. However, remarkable reduction in HAZ and respective increase in hardness of first buttering layer owing to PWHT has been evidenced. Hence, the use of buffer layer provides the desirable hardness profile across the interface. There is negligible risk of carbon migration during PWHT and tempering of martensite in buffer layer to achieve the stress relieving due to the employment of the buffer layer.

\section{Conclusions}

1. Use of Ni-Fe buffer layer leads to lowering the composition gradient by splitting it into two locations, whereas the large composition gradient exists using Inconel 82 as buttering without buffer layer.

2. The $\mathrm{Fe}-\mathrm{Ni}-\mathrm{C}$ martensite forms at ferritic steelInconel 82 and ferritic steel- $\mathrm{Ni}-\mathrm{Fe}$ alloy interface. The estimated thickness of martensite at ferritic steel-Inconel 82 and $\mathrm{Ni}-\mathrm{Fe}$-Inconel 82 interface is $\sim 2 \mu \mathrm{m}$, whereas it is $\sim 6 \mu \mathrm{m}$ for ferritic steel- $\mathrm{Ni}-\mathrm{Fe}$ alloy interface.

3. Diffusivity of carbon from ferritic steel to first layer is significantly higher in weld pad without buffer layer (Inconel 82 buttering) than the weld pad with buffer layer. Diffusivity of carbon is inverse in case of third to fourth layer with buffer layer weld pad, while diffusion (very less) exists in weld pad without buffer layer from third layer to fourth layer. Diffusivity in aged condition is considerably less than as-buttered condition in both weld pads. However, carbon diffusion could exist at operating temperature $\left(330^{\circ} \mathrm{C}\right)$ and that is more in weld pad without buffer layer than with buffer layer weld pad. Use of Ni-Fe alloy buffer layer in Inconel 82 buttering deposit can significantly control the carbon migration.

4. Significant formation of decarburized soft zone of ferrite phase field in HAZ of ferritic steel exists in weld pad of Inconel 82 buttering without buffer layer. However, carbon-enriched zone exists because of $\mathrm{Ni}-$ Fe buffer layer. This can confirm the control of carbon migration due to $\mathrm{Ni}-\mathrm{Fe}$ buffer layer in Inconel 82 buttering deposit. Considerable degradation mechanism of soft zone formation owing to Inconel 82 buttering can be prevented using $\mathrm{Ni}-\mathrm{Fe}$ buffer layer. Ageing effect at $450{ }^{\circ} \mathrm{C}$ is also significant in HAZ of ferritic steel without buffer layer than with buffer layer deposit.

5. Undesirable carbide precipitates exist in first layer of Inconel 82 buttering, while undiluted ferrite with martensite structure exists in first layer (buffer) of Ni$\mathrm{Fe}$ alloy. Considerable variations caused in subsequent buttering layer of Inconel 82 owing to buffer layer in terms of size and structure of phases. The changes in phase structure and size of phase particles also exist due to ageing temperature $450{ }^{\circ} \mathrm{C}$.

6. Micro-hardness variations are more favourable in weld pad with buffer layer than without buffer layer. Peak hardness reduced at interface with buffer layer due to tempering of martensite during PWHT. Undesirable changes exist at the interface of ferritic steel-Inconel 82 (without buffer layer) owing to PWHT, while 
favourable variations in hardness exist at the interface of weld pad with buffer layer due to PWHT.

7. Present investigation of metallurgical characterization and carbon diffusion study suggests the use of $\mathrm{Ni}-\mathrm{Fe}$ buffer layer in Inconel 82 buttering to control the carbon migration and could be the better choice for DMW joint requirement on metallurgical properties and carbon diffusion ground/basis.

Acknowledgments The authors acknowledge the support given by Board of Research in Nuclear Sciences, Department of Atomic Energy (India) for present work (No. 2008/36/107-BRNS/4038A). Authors are also thankful to the Defense Metallurgical Research Laboratory (Ministry of Defense, India) for providing EPMA facility in diffusion-related study. The help extended by Mr. Paul English, Specialist Welder, MTRL, UoM is also highly appreciated.

\section{References}

[1] R. Miteva, N.G. Taylor, in E. Commission (Ed.) NESC Report, Institute for Energy, Netherland (2006)

[2] A.K. Bhaduri, S. Venkadesan, P. Rodriguez, P.G. Mukunda, Int. J. Press. Vessels Pip. 58, 251 (1994)

[3] C.D. Lundin, Weld. Res. Suppl. 61, 58s (1982)

[4] M. Sireesha, S.K. Albert, V. Shankar, S. Sundaresan, J. Nucl. Mater. 279, 65 (2000)

[5] A. Celik, A. Alsaran, Mater. Charact. 43, 311 (1999)

[6] M. Sireesha, V. Shankar, S.K. Albert, S. Sundaresan, Mater. Sci. Eng. A 292, 74 (2000)

[7] C.R. Das, A.K. Bhaduri, G. Srinivasan, V. Shankar, S. Mathew, J. Mater. Process. Technol. 209, 1428 (2009)

[8] Y.Y. Ying, S.R. Kae, S.R. Haur, C. Chun, J. Mater. Sci. Lett. 20, 1429 (2001)

[9] R. Anand, C. Sudha, V.T. Paul, S. Saroja, Suppl. Weld. J. 89, 65s (2010)
[10] D.W. Rathod, S. Aravindan, P.K. Singh, S. Pandey, ISIJ Int. 54, 1866 (2014)

[11] H.-L. Ming, Z.-M. Zhang, P.-Y. Xiu, J.-Q. Wang, E.-H. Han, W. Ke, M.-X. Su, Acta Metall. Sin. (Engl. Lett.) 29, 848 (2016)

[12] J.N. DuPont, S. Babu, S. Liu, Metall. Mater. Trans. A 44A, 3385 (2013)

[13] J.N. Dupont, C.S. Kusko, Weld. J. 86, 51s (2007)

[14] D.W. Rathod, P.K. Singh, S. Pandey, S. Aravindan, Mater. Sci. Eng. A 666, 100 (2016)

[15] R.E. Avery, in, Nickel Development Institute, Reprinted with permission from Chemical Engineering Progress May 1991, American Institute of Chemical Engineers, NiDI reprint series No 14018, (1991)

[16] D.W. Rathod, S. Pandey, P.K. Singh, R. Prasad, Mater. Sci. Eng. A 639, 259 (2015)

[17] D.W. Rathod, S. Pandey, P.K. Singh, R. Prasad, J. Press. Vessel Technol. 138, 011403 (2016)

[18] J.C. Lippold, D.J. Kotecki, Welding metallurgy and weldability of stainless steels, 1st edn. (Hoboken, New Jersey: John Wiley \& Sons, Wiley Interscience Publication, 2005)

[19] W.H. Minnick, M.A. Prosser, Manual welding of dissimilar metals, in Gas Tungsten Arc Welding Handbook, 6th ed. (Goodheart-Willcox Publisher, 2013), pp. 203-212

[20] J.N. DuPont, J.C. Lippold, S.D. Kiser, Welding Metallurgy and Weldability of Nickel-Base Alloys, 1st edn. (Wiley Publications, Hoboken, 2009)

[21] J.N. DuPont, R.E. Mizia, Review of dissimilar metal welding for the NGNP helical coil steam generator, Idaho National Laboratory, Idaho Falls, Idaho, INL/EXT-10-18459, (2010)

[22] J.N. Dupont, S.W. Banovic, A.R. Marder, Weld. J. 82(6), 125s (2003)

[23] R. Dehmolaei, M. Shamanian, A. Kermanpur, Mater. Charact. 59, 1447 (2008)

[24] G. Srinivasan, A.K. Bhaduri, in Proceedings of 63rd Annual Assembly \& International Conference of the International Institute of Welding, Istanbul, Turkey, 2010, pp. 81-87

[25] B.J. Lee, H.D. Kim, J.H. Hong, Metall. Mater. Trans. A 29A, 1441 (1998) 